\title{
Tourism, smallness and insularity: a suitable combination for quality of life in Small Island Developing States (SIDS)?
}

\author{
Miguel Puig-Cabrera \\ Facultad de Turismo y Finanzas, Universidad de Sevilla, Spain \\ migpuicab@alum.us.es (corresponding author)

\section{Concepción Foronda-Robles} \\ Facultad de Turismo y Finanzas, Universidad de Sevilla, Spain \\ foronda@us.es
}

\begin{abstract}
As Small Island Developing States (SIDS) turn into a focus of attention for tourists and foreign investment, tourism becomes one of the primary sources of wealth in these economies. This increasing relevance of tourism in SIDS in turn becomes an opportunity not only to enhance the residents' quality of life but also to combat the existing vulnerabilities of SIDS. The main goal of this research is to measure the effects of tourism on the quality of life of residents in SIDS according to: 1) the degree of tourism development, 2) the allocation of public and private resources to promote the tourism sector, and 3) the direct opportunities that tourism offers to the populations in SIDS. In order to do so, an empirical analysis has been carried out based on a panel database containing data from 28 SIDS during the period 2005-2016. The findings suggest that tourism development becomes a driving force for enhancing the residents' quality of life. It is also proven that government expenditure has a positive effect on the population, with a repercussion four times greater than that of private investment. Finally, work precarity appears to be a reality in SIDS.
\end{abstract}

Keywords: islands, private investment, quality of life, Small Island Developing States (SIDS), small economic size, tourism development

https://doi.org/10.24043/isj.95 • Received March 2019, accepted August 2019

(C) 2019-Institute of Island Studies, University of Prince Edward Island, Canada.

\section{Introduction}

Small Island Developing States (SIDS) are characterized by their small size. This condition intrinsically implies a series of factors that make these destinations more vulnerable, which are: a) smallness: the population, land area, and/or GDP are small; b) insularity and remoteness: a lack of effective and efficient transport; c) being prone to natural disasters; d) environmental vulnerability and fragile ecosystems; e) dependence on foreign economies; and f) the need for greater flexibility in order to adapt to global changes (Briguglio, 1995; Moghal \& O’Connell, 2018; Naudé et al, 2009). 
These features give rise to a situation of persistent socioeconomic volatility (Jackman, 2014; Read, 2018), which conditions the residents' quality of life (QoL) (McAlber et al, 2005; Shareef \& McAleer, 2005), and a vulnerability that directly harms this QoL may be present in most SIDS if appropriate measures are not taken (Scheyvens \& Momsen, 2008).

Although tourism activity no doubt has a considerable effect on any destination, regardless of its size, location, and sociopolitical circumstances, tourism represents an area of strength for SIDS. Forecasts for the global tourism market suggest that by the year 2030 emerging destinations and SIDS will have acquired a greater market share than traditional destinations (UNWTO, 2018a). In 2014, the SIDS Accelerated Modalities of Action (SAMOA) Pathway (UN, 2014) recognized tourism as an important route to job creation, income generation, education, poverty reduction, and sustainable development in these economies. Subsequently, the First World Conference on Tourism for Development (UNWTO, 2016) highlighted the need to measure the real effects of tourism on residents' QoL in emerging destinations so that some of the main goals of Agenda 2030 might be achieved.

The inclusion of tourism in Agenda 2030 implies the expectation that this activity will enhance residents' QoL by contributing to the accomplishment of some of the Sustainable Development Goals (SDGs) for SIDS, such as: a) affordable and clean energy (Praene et al, 2018; Surroop et al, 2018); b) a reduction in inequality by attracting foreign investment and having efficient coordination of public initiatives (Sari, 2017); c) tackling climate change (Hess \& Kelman, 2017; Robinson, 2017); and d) the sustainable use of marine resources (Alder et al, 2018; Kapmeier \& Gonçalves, 2018).

QoL can traditionally be defined as "the ability of people to lead the kind of life they have reason to value. It is the enhancement of the capability to live better and richer lives, through more freedom and opportunity" (Anand \& Sen, 2000).

The literature addresses QoL from two different perspectives: in terms of its objective and its subjective dimension (Ridderstaat et al, 2016). The first involves objective properties such as conditions and resources, which are independent of a person's awareness (Karimi \& Brazier, 2016; Lotfi \& Koohsari, 2009). The subjective or emotional dimension is composed of feelings and perceptions about life based on emotions (Andereck \& Nyaupane, 2011; Genc, 2012; Uysal et al, 2016).

Given the peculiarities of SIDS, the tourism-QoL interaction becomes crucial (McElroy, 2006; Seetanah, 2011). Thus, tourism becomes not only a driver for the improvement of QoL, but also an opportunity to turn the vulnerabilities of these economies into a global competitive advantage (UNWTO, 2015, 2018b) in order to boost economic development.

With only $1 \%$ of the world's population living in SIDS, tourism in these states attracts approximately $3.75 \%$ of the global share, and in many cases accounts for more than $20 \%$ of the national GDP (UNWTO, 2015).

The main objective of this study is to measure the effects of tourism on residents' QoL in SIDS according to: 1) the degree of tourism development, 2) the allocation of public and private resources to promote the tourism sector, and 3) the direct opportunities that tourism offers to the populations in SIDS. To this end, an empirical analysis has been carried out based on a panel database containing data from 28 SIDS over the period 2005-2016.

After this introduction, there is a literature review, together with a presentation of the hypotheses to be tested. The third section describes the data collection and the study sample used in this work. The fourth section explains the methods used to carry out the panel data 
analysis. The fifth section contains the findings of the analysis as well as the discussion of these findings; this section also contains some recommendations for Destination Management Organizations (DMOs). Finally, a set of conclusions is provided.

\section{Literature review}

Due to their size, SIDS require greater momentum than other economies to boost economic development (McGillivray et al, 2010). Numerous studies address the causal relationship tourism-QoL in a bidirectional fashion. Thus, tourism is analyzed both in terms of its effects on residents' QoL (Andereck \& Nyaupane, 2011; Kim et al, 2013; Uysal et al, 2016), and as a consequence of enhancing QoL (Ridderstaat et al, 2016; Woo et al, 2015; Yu et al, 2016).

Several hypotheses have been formulated in the existing literature in order to analyze the interaction between key elements of the tourism-QoL nexus in SIDS, these elements being: 1) the degree of tourism development, 2) the allocation of public and private resources to promote the tourism sector, and 3) the direct opportunities that tourism offers to the populations in SIDS.

\section{The QoL-tourism development (QoL-Develop) interaction}

Tourism has always been associated with economic development (Cannonier \& Burke, 2018; Chou, 2013; Fahimi et al, 2018), thus affecting residents' QoL (Ridderstaat et al, 2016; Schubert et al, 2011).

Some authors suggest that tourism development contributes to economic prosperity and development (Read, 2018; Singh, 2008; UNWTO, 2018b). However, others stress that this activity tends to aggravate the poverty of residents (Gascón, 2015; Lee et al, 2014; Scheyvens \& Russell, 2012) and worsen their QoL.

Pratt (2016) argues that while tourism generates a significant amount of economic activity, the income that remains in the destinations is insubstantial. Suntikul et al (2016) provide empirical evidence at a microeconomic level for the case of Hue (Vietnam), where the residents perceived tourism as an opportunity to benefit the community as a whole without it being enough to enhance their QoL as individuals.

In spite of these different hypotheses, there is an absolute consensus on the positive effects of the QoL-Develop interaction in small-size economies such as SIDS (UNWTO, 2015). The greater the number of tourist arrivals and the greater the subsequent increase in incomes, the more positive are the effects of this sector on residents' QoL in these destinations (Banwayo-Skeete \& Skeete, 2015; Croes \& Rivera, 2010; Ridderstaat et al, 2016).

Taking the above into account, the QoL-Develop interaction is hypothesized as:

Hypothesis 1: Tourism development in SIDS contributes to residents' QoL in a positive way.

\section{The QoL-tourism promotion (QoL-Promot) interaction}

The only way in which tourism can benefit the population in a destination is by developing tourism activity. However, this very development requires enough existing tourism infrastructure and services for tourists not only for when they arrive at the destination, but also to fulfil their needs during the stay (Andrades \& Dimanche, 2017). Given its particular characteristics, this situation in SIDS is even more complex (Moghal \& O'Connell, 2018). 
The intervention of public and private initiative in a destination is a critical element in making tourism possible. For example, without tourism promotion, the benefits of tourism would not be accessible to the population. The allocation of public or private resources to the tourism sector is essential (Chou, 2013; Uysal et al, 2016), not only as a contribution to an improvement in QoL, but also in order to make a destination more competitive.

Foreign investment is a key component in the tourism infrastructure in SIDS, with most of the capital investment coming from outside these economies (UNCTAD, 2018), which import not only capital but also skills and ITC resources (Isik, 2015). For example, SIDS need to develop an effective transport infrastructure so that tourism can be developed by residents (Pentelow \& Scott, 2011), or have a first-rate hotel (Prayag et al, 2010).

In addition, effective tourism policies and special grants are needed to ensure that the local community can benefit from the tourism sector (Sharpley \& Ussi, 2014).

To put it shortly, unless there are enough tourism facilities and services in a destination, tourism will not be able to function properly.

The QoL-Promot interaction is supposed to affect the populations in SIDS positively, by providing the means by which tourism can be made a reality and the destinations can be made more competitive (Croes, 2013; Crouch \& Ritchie, 2012):

Hypothesis 2: As tourism promotion in SIDS increases, so does the residents' access to benefits, this enhancing their QoL.

\section{The QoL- job opportunities (QoL-Opport) interaction}

Tourism acounts for one in every 12 jobs worldwide, either directly or indirectly (UNWTO, 2018b). Some studies have analyzed the tourism-QoL nexus in terms of the number of opportunities (jobs) that tourism offers to residents (Andereck \& Nyaupane, 2011; Liburd et al, 2012) in emerging destinations. Others, however, claim that the evidence provided is questionable, as these jobs immerse workers in a precarious environment (Suntikul et al, 2016), and may imply low wages, long working days, stressful conditions, and few opportunities for promotion (Lee et al, 2014).

In the case of SIDS, tourism is included in the corresponding policy agendas (Shakeela et al, 2011) as a way of improving residents' QoL by creating new jobs.

The tourism sector also contributes to building and strengthening value chains with other activities in a destination, such as agriculture or handicrafts. In small economies like SIDS, this multiplier effect can be even more rewarding (UNWTO, 2015).

For the purpose of the current study, the QoL-Opport interaction is supposed to be beneficial to the residents of SIDS:

Hypothesis 3: The more the number of jobs related to the tourism sector increases in SIDS, the more the residents' QoL is enhanced as they are offered new opportunities.

\section{Data}

The effects of tourism on SIDS are still disputed in the academic community (Pratt, 2015). In order to clearly define and resolve this dilemma, the current empirical analysis covers the period 2005-2016 and contrasts the effects of tourism on the QoL of the populations of SIDS. 
Although the time period of the research contains three different economic cycles (precrisis, financial crisis, and post-crisis), it has been assumed that tourism is a resilient sector (Cellini \& Cuccia, 2015), which means that regardless of the global macroeconomic situation, it tends to grow gradually (WTTC, 2016).

Podhorecka (2018) states that in spite of the global recession in the tourism market, in the case of SIDS there has been an increase rather than a decrease in the number of tourists and expenditure, and even the number of jobs linked to this sector.

An innovation of this research is that it goes beyond a strictly monetary vision to one of economic development analyzed from a multidimensional perspective (UNDP, 2018) that concerns the population's access to a better standard of living, as well as to what extent its educational and health needs are covered.

\section{Study sample}

Based on UN (2018) classification, a panel data analysis was carried out for 28 SIDS worldwide, all of which are UN member states, for the period 2005-2016.
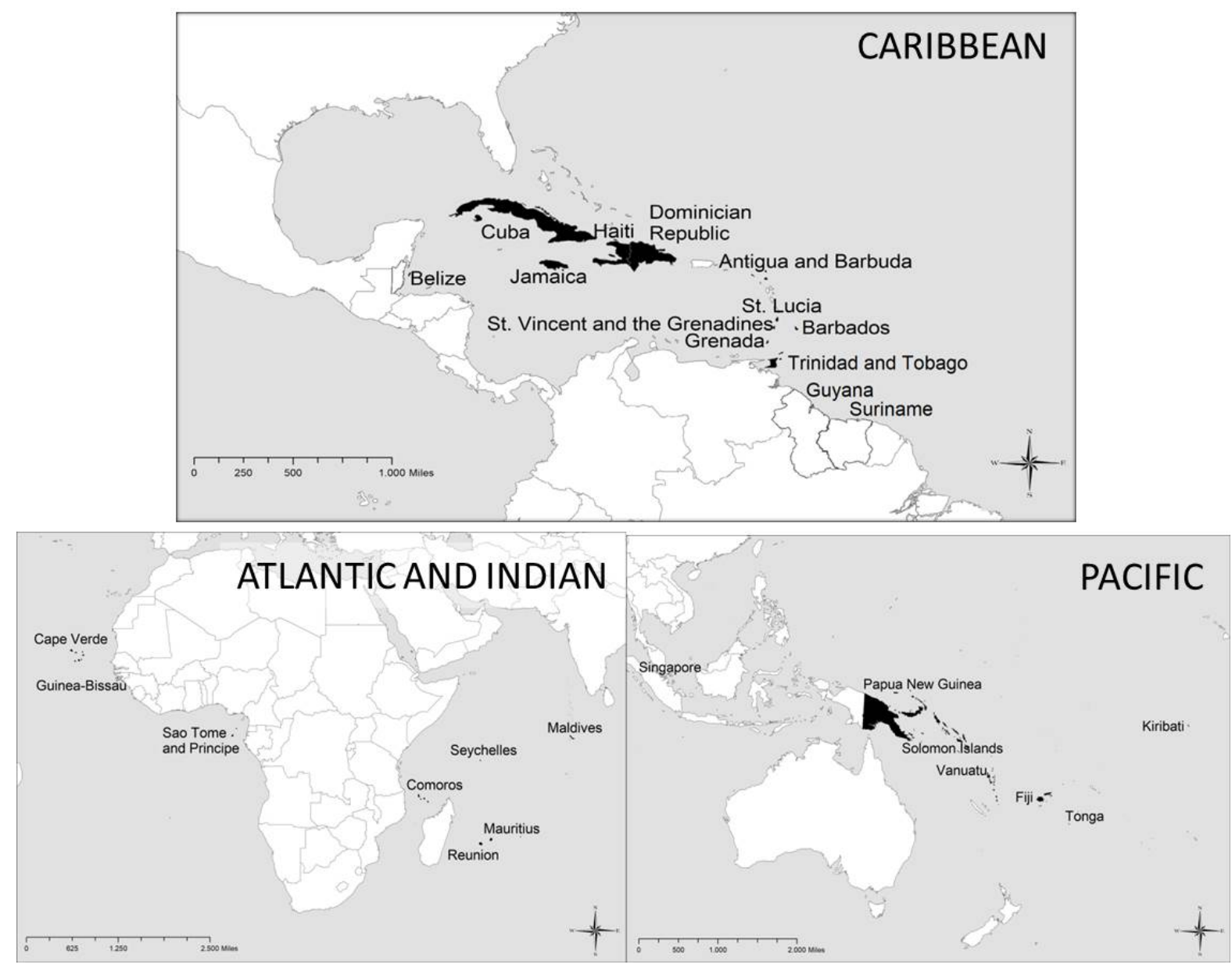

Figure 1: Study sample.

The study sample used for this research was defined by data availability (Figure 1). Thus, $100 \%$ of the SIDS analyzed are UN member states (28 out of the 38 existing SIDS that are member states). The coverage of this research is worldwide, and includes SIDS from the 
Atlantic Ocean, the Indian Ocean, the Mediterranean Sea, the South China Sea, the Caribbean and the Pacific Ocean.

Although not all island states are consolidated tourism destinations, the main contribution of this paper is to show that, in general, tourism activity contributes to an improvement in the QoL of those island states not only in economic, but also in societal and health terms.

\section{Description of variables}

The variables used in this analysis have been included based on their suitability for measuring the way in which the tourism phenomenon affects residents' QoL according to: 1) the degree of tourism development, 2) the promotion of this activity by public and private initiatives, and 3) the direct opportunities that it offers to residents (Figure 2).

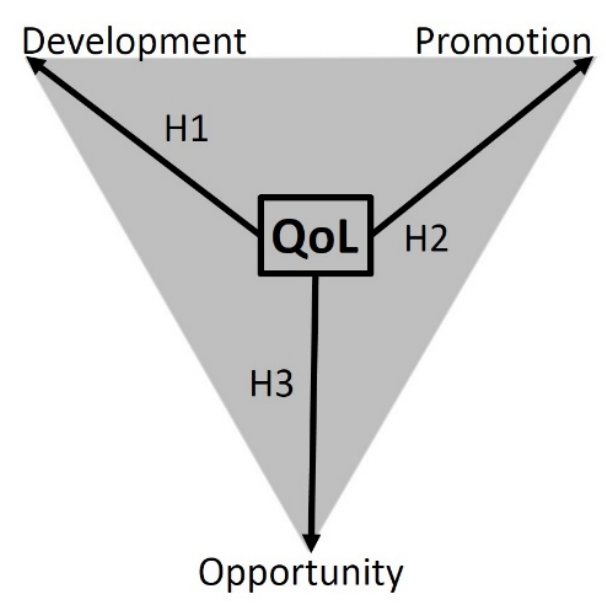

Figure 2: Conceptual scheme of tourism and QoL.

The Human Development Index (HDI) was obtained from the United Nations Development Programme (UNDP, 2018) in order to measure the QoL achieved by the populations in the chosen time horizon (2005-2016). According to Anand and Sen's (2000) statement, this index was created as a proxy for QoL, by measuring longevity, education, and "command over resources to enjoy a decent standard of living" (UNDP, 1990). Thus, the construct of QoL in this research is based on a three-dimensional approach: income, education and health (Haq \& $\mathrm{Zia}, 2013$ ). Since the HDI is a traditional and accepted indicator for measuring QoL (Rahman et al, 2005), it is used in research in different sectors, such as trade (Davies \& Quinlivan, 2006) or tourism (Kubickova et al, 2017).

The values of the HDI range from 0 to 1 point, with 0 representing the situation closest to underdevelopment (low standard of living, and unsatisfied educational and health needs), and 1 the situation of maximum development (high standard of living, and educational and health needs are met).

In order to analyze tourism development in SIDS, two variables have been included: Tourism Arrivals (TA) and Tourism GDP (TGDP). TA was extracted from UNWTO's (2018a) Compendium of Statistics for all the periods considered in this research. This variable quantifies the total amount of tourists heading to SIDS per year. TGDP was chosen as an indicator that 
represents the relevance of tourism within the whole economy of SIDS. The TGDP data was taken from the WTTC (2018) database in billions (bn) of US dollars (real prices).

The promotion of tourism by actors in SIDS has been measured from both a public and a private perspective: Private Investment in Tourism (PI) and Government Tourism Expenditures (GTE). PI includes capital investment spent by any of the industries directly involved in the tourism sector (e.g., transport infrastructure, accommodation, and restaurants). GTE refers to government spending on tourism services of two types: cultural (e.g., cultural sites and museums) and natural (e.g., national parks and other natural attractions). Both variables were extracted from the WTTC (2018) database in billions (bn) of US dollars (real prices).

There are two other variables that have been included in the empirical analysis: Direct Contribution of Tourism to Employment (DirE) and the Economic Freedom Index (EFI). DirE measures the number of opportunities (jobs) generated by tourism development. The EFI is an index that reflects the political and economic situation in SIDS, with 0 representing the least free situation, and 100 the freest. The latter variable is used in this research as a proxy. DirE was taken from the WTTC (2018) database in thousands of jobs, while the EFI was taken from the Heritage Foundation (2018).

Table 1: Summary statistics of the variables used in the regressions.

$\begin{array}{llllll} & \text { Mean } & \text { Std. Dev. } & \text { Min. } & \text { Max. } & \text { Obs. } \\ \text { HDI } & 0.673 & 0.108 & 0.396 & 0.930 & 336 \\ \text { TA }^{*} & 12.300 & 1.771 & 8.268 & 16.373 & 336 \\ \text { TGDP }^{\star} & -0.669 & 1.718 & -4.605 & 3.412 & 336 \\ \text { PI }^{\star} & -2.475 & 1.608 & -4.715 & 2.683 & 336 \\ \text { GTE }^{\star} & -1.215 & 1.809 & -4.605 & 2.721 & 336 \\ \text { DirE* } & 2.684 & 1.443 & -0.011 & 5.314 & 336 \\ \text { EFI } & -0.089 & 5.374 & -41.8 & 32.8 & 336\end{array}$

* Variables converted to natural logs in the analysis.

\section{Methods}

\section{Regression model}

Previous studies suggest that tourism contributes to enhancing the QoL of a destination's residents (Pilkington et al, 2017; Telfer \& Sharpley, 2016; UNWTO, 2018b). The literature also argues that economy size plays a key role in tourism and development (UNWTO, 2015, 2018b): the smaller the economy, the greater its contribution to enhancing the residents' QoL (Chou, 2013; Dritsakis, 2012).

According to the hypotheses formulated in previous sections, the following functional relationships have been put forward:

$$
Q_{\text {oL }}=f\left(\text { Develop }_{i t}, \text { Promot }_{i t}, \text { Opport }_{i t}\right)(1
$$

Where QoL is the quality of life of the population in SIDS; Develop measures the degree of development of tourism activity; Promot evaluates the promotion of tourism by public and 
private initiatives; Opport is the direct job opportunities that tourism offers to residents; while $i$ is a subindex that refers to the study sample (a total of 28 SIDS) and $t$ is a subindex that refers to the period of time covered in this research (2005-2016).

Based on Equation 1, a panel data analysis was carried out on 28 SIDS for the period 2005-2016 using the ordinal least square (OLS) method:

$$
H D I=A_{i t}+\beta_{1} T A_{i t}+\beta_{2} T G D P_{i t}+\beta_{3} P I_{i t}+\beta_{4} G T E_{i t}+\beta_{5} D i r E_{i t}+e_{i t}(2
$$

Where HDI stands for the Human Development Index; TA for Tourism Arrivals; TGDP for Tourism GDP; PI for Private Investment of Capital in Tourism; GTE for Government Tourism Expenditures; DirE for Direct Contribution of tourism to Employment; $A$ is the sum of individual and temporal effects; and $e$ represents the error term.

Tourism research uses TA and TGDP as key variables to measure the relevance of tourism in a destination (Hafiz et al, 2017; Khan et al, 2017; Pulido-Fernández et al, 2015) and in SIDS (Cannonier \& Burke, 2018; Shareef \& McAleer, 2005). Thus, in the current study these two variables are used to represent tourism development in SIDS (Develop in Equation 1).

In order to measure the promotion of tourism (Promot in Equation 1) in SIDS, two variables have been used in this research for private and then public initiative: PI is considered to be an important component in tourism development research for the evaluation of the effects of private investment on the population (Tang \& Abosedra, 2016), especially in SIDS (Duffy et al, 2016; Fauzel et al 2017); and GTE is a crucial variable that measures the effects of government tourism expenditures on the residents of SIDS (Banerjee et al, 2015).

DirE is used in tourism and development research as an indicator to evaluate the real opportunities (Opport in Equation 1) of residents to gain access to a better QoL in SIDS (Baum, 2012; Lee et al, 2014; Scheyvens \& Russell, 2012).

Napierian logarithmic transformation $(L n)$ was used to induce stationarity in the time series, thus assuring that the statistical properties are all constant over time. This implies Equation 1 being transformed into a level-log model (Grampella et al, 2016). In addition, a deep analysis of the properties of the series was carried out. Pesaran's (2004) cross-sectional dependence, as well as his unit root (Pesaran, 2007) and cointegration (Westerlund, 2008), was tested. The stationarity test was undertaken in both of its forms: level and first difference. The first difference form $(\Delta)$ was used to obtain better parameter estimates of Equation 1:

$$
H D I=A_{i t}+\beta_{1} \operatorname{Ln} T A_{i t}+\beta_{2} \operatorname{LnTGDP_{it}}+\beta_{3} \operatorname{Ln} P I_{i t}+\beta_{4} \operatorname{LnGTE_{it}}+\beta_{5} \operatorname{LnDir} E_{i t}+e_{i t}
$$

The method used in Equation 2 was panel-corrected standard errors (PCSE), in order to solve issues of contemporaneous correlation (Dufour \& Khalaf, 2003), heteroskedasticity (White, 1980) and autocorrelation (Andrews, 1991) among variables. Beck and Katz (1995) showed that the PCSE method offers more precise results than the so-called feasible generalized least square (FGLS) estimator. Multicollinearity among the explanatory variables was also analyzed, in this case by using the values of the variance inflation factors (VIFs). 
Table 2: Variance inflation factors.

$\begin{array}{ll}\text { Variables } & \text { VIF (Variables) } \\ \text { LnTA } & 1.11 \\ \text { LnTGDP } & 2.29 \\ \text { LnPI } & 1.14 \\ \text { LnGTE } & 2.46 \\ \text { LnDirE } & 2.59 \\ \text { Mean VIF } & 1.95\end{array}$

The higher the VIF values, the greater the probability of existing multicollinearity.

Even though a VIF value $<10$ is acceptable for proving a lack of multicollinearity, the VIF values of all of the variables in the model are $<3$ (Table 2), in this way conforming to a stricter criterion (Hair et al, 1995).

\section{Results and discussion}

All of the regression coefficients in Equation 3 are significant at level 0.01, except for LnGE, which is significant at level 0.05 (Table 3).

The Wald chi-square statistics test (Prob $>$ chi2 $=0.0000)$ confirms that the null hypothesis is to be rejected, which means that none of the regression coefficients in the model are equal to zero. The test thus concludes that all of the variables included in the model are not simultaneously equal to zero, as the test creates a statistically significant enhancement in the fit of the model.

According to the determination coefficient $\left(\mathrm{R}^{2}=0.651\right)$, it is to be confirmed that a $65.1 \%$ variation of $\mathrm{HDI}$ can be explained by the $\mathrm{X}$ covariates. Contemporaneous correlation, heteroskedasticity and autocorrelation among variables were corrected using the PCSE method. It is thus confirmed that the model is valid.

Table 3: Results of estimations.

\begin{tabular}{|c|c|c|c|}
\hline & Coefficient & Standard Error ${ }^{a}$ & $\mathbf{P}>|\mathbf{z}|$ \\
\hline LnTA & $0.011 \star \star \star$ & 0.0012 & 0.000 \\
\hline LnTGDP & $0.009 \star \star \star$ & 0.0025 & 0.001 \\
\hline LnPI & $0.001 \star \star \star$ & 0.0007 & 0.005 \\
\hline LnGTE & $0.006 \star \star$ & 0.0021 & 0.013 \\
\hline LnDirE & $-0.009 \star \star \star$ & 0.0025 & 0.005 \\
\hline $\mathrm{R}^{2}$ & 0.651 & & \\
\hline Wald chi2 & 46.32 & & \\
\hline Prob $>$ chi2 & 0.0000 & & \\
\hline
\end{tabular}

The findings confirm that tourism contributes to the enhancement of QoL in SIDS, as other studies have assumed (Cannonier \& Burke, 2018; Fauzel et al, 2017; Seetanah, 2011). 
In the analysis of these results, the ceteris paribus principle should be taken into account. So, the effect of one variable on another must be considered while all of the other variables of the model remain constant.

\section{Findings in the QoL-Develop interaction}

The results of the QoL-Develop interaction suggest that greater tourism development contributes to enhancing the living conditions of the population in SIDS (Table 3), so Hypothesis 1 can be accepted. Concerning LnTA, every additional tourist heading to SIDS would increase the HDI by $1 \%$ ceteris paribus.

LnTGDP also has a positive effect on the HDI: as tourism GDP increases by one billion US dollars (\$US), the HDI does so by $0.9 \%$. So, it can be affirmed that as tourists visit SIDS and spend money there, the residents' QoL is enhanced. These findings confirm those of previous research into SIDS (Croes, 2013; Jiang et al, 2011).

The literature states that tourism leakage is a common problem in developing destinations (Hampton et al, 2018), as a large part of the income derived from tourism is redirected to other economies, instead of remaining in the destination (Suryawardani et al, 2014). There are examples of developing destinations where around $78.5 \%$ of whose tourism earnings leaks to other economies (Puig-Cabrera \& Foronda-Robles, 2018). This is also a problem for SIDS.

Pratt's study (2015) argues that for every $\$ 1.00$ spent in one of the SIDS (American Samoa, Aruba, Fiji, Jamaica, Mauritius, Seychelles, and Samoa), only $\$ 0.69$ on average stays in the local economy, and in the case of American Samoa only $\$ 0.44$.

Sharpley (2009) comments on the case of The Gambia. In the year 2000, this destination banned all-inclusive holiday packages so that the population could have greater access to income from tourism. Unfortunately, tourist arrivals decreased substantially as a result, and this policy was revoked.

The fact that LnTA has a more significant effect than LnTGDP on the HDI could be explained by what we, the authors, have called the "tourist attachment" effect. This effect is determined by the existing degree of tourism "decentralization" in SIDS. Thus, the greater the out-of-pocket tourist expenditure in the local economy, the more fully can the benefits of tourism be taken advantage of by the residents.

\section{Findings in the QoL-Promot interaction}

Hypothesis 2 is confirmed, as the findings suggest that both private capital investment in tourism and government tourism expenditures contribute positively to the residents' QoL in SIDS (Table 3). This implies that the QoL-Promot interaction in SIDS is positive, and similar results for SIDS confirm this (Fauzel et al, 2017; Scheyvens \& Russell, 2012).

According to LnPI, the billions of dollars coming from private investment increase the HDI by $0.16 \%$, while the LnGTE coefficient indicates that if the same billions of dollars come from public initiative, their contribution to the HDI is $0.66 \%$. Thus, the effect of government tourism expenditures is four times greater than that of private capital investment. It is important to emphasize that an important share of the capital investment related to tourism in SIDS is foreign (UNCTAD, 2018), with these destinations becoming an increasing focus of interest to foreign tourists. Some authors even state that the current high level of foreign 
investment in SIDS makes these destinations much more dependent on transnational companies (Lee et al, 2014).

It can be assumed that tourism promotion within SIDS fosters an endogenous model of development that allows the public administration to increase the residents' QoL. Even so, it is also true that foreign investment in SIDS may become the only way to make tourism a reality in these destinations, as it builds the necessary infrastructure, promotes tourism resources, and has the power to turn them into "attractive" places to visit (UNCTAD, 2007). It is important to remark that air and sea connectivity provides a vital lifeline for SIDS, where not only the availability of this connectivity but also the reliability and the affordability become essential issues (UNWTO, 2018b). According to Butler's model (1980), this fact is especially relevant to SIDS in the initial stages of tourism development.

\section{Findings in the QoL-Opport interaction}

One of the most direct effects of large-scale enterprises in SIDS (e.g., resorts, cruises, and airlines) is job generation, which, theoretically, should contribute positively to the residents' QoL, since it offers new opportunities.

According to Table 3, it can be assumed that LnDirE has the opposite effect on the HDI. Every thousand jobs generated in the tourism sector reduces the HDI by $0.9 \%$. This finding means that Hypothesis 3 should be rejected and the null hypothesis accepted.

Suntikul et al (2016) point out that even though tourism is an important job generator, the quality of these jobs does not fulfil the conditions that the population really expects and needs. Some studies even argue that the greater the number of international firms that have settled in SIDS, the greater the labour precarity in the destination (Lee et al, 2014). Scheyvens \& Russell (2012), in turn, claim that a lack of local entrepreneurship is one of the main reasons for labour precarity in the tourism sector in SIDS.

On the other hand, a correlation analysis was carried out during the initial stages of the current research, and despite no causation being found, the findings suggest that the number of tourist arrivals (LnTA) and the economic freedom index (EFI) have a strong correlation.

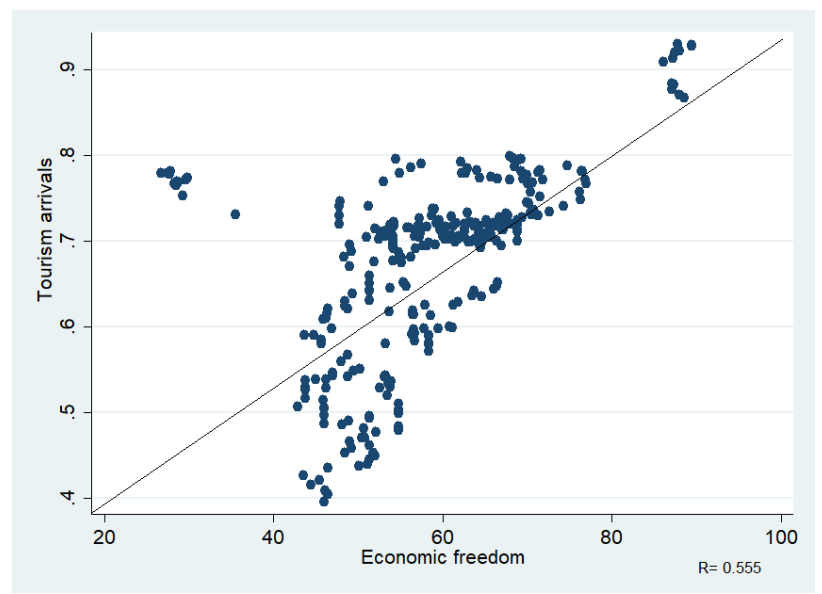

Figure 3: The correlation between tourist arrivals and economic freedom.

Figure 3 indicates the correlation between LnTA and the EFI. The results show that there is a direct relationship between the two variables, this being highly significant as regards the 
two-tailed Pearson correlation $(\mathrm{r}=0.555, \mathrm{p}<0.01)$. Given the nature of the relationship, no causation can be identified. Therefore, it only can be concluded that greater economic freedom is linked (as cause or effect) to a greater number of tourist arrivals in SIDS.

Several aspects have been identified below related to the tourism-QoL nexus in SIDS that DMOs should take into account in order to ensure tourism benefits for the population:

Firstly, the "tourist attachment effect" suggests the need to promote the direct hiring of local services. One of the main problems in SIDS is that the predominant model of tourism development is all-inclusive package based. This limits the access of residents to the benefits of tourism, as a significant part of the tourists' stay has been previously planned and booked.

In order to solve this problem, governments could grant some advantages to local entrepreneurs, such as offering them the exclusive rights to manage certain tourist attractions and sites. Such action could help to decrease the amount of earnings from tourism that leak to other economies.

According to the Pigou-Dalton condition (Dalton, 1920; Pigou, 1912), a country reaches higher levels of QoL as its wealth becomes more equally distributed. As regards the tourism sector, it is to be assumed that this activity is a route to economic prosperity. Thus, tourism development in SIDS should become an opportunity to enhance the residents' QoL by assuring access to earnings from tourism. In the cases of SIDS with more severe leakage problems, DMO's should design policies for the distribution of earnings from tourism that consist of restricting the amount of money that returns to other countries. Tax incentives might be granted to those foreign companies that reinvest profits in destinations, and also according to the number of local people employed by and even the level of responsibility to them assumed by one of these companies.

In the case of international tour operators, there must be a guarantee that a certain percentage of the total services offered in the package are supplied by local businesses. If the amount of money returning to other economies appears to be a severe problem in a destination, then gradual economic sanctions might be imposed. So, the more the money that a foreign company takes to another country, the higher the percentage that should be paid to the competent authorities.

This sort of policy would have an invigorating effect on the economies of SIDS, as a more significant proportion of the international tourism companies' net profits would be retained.

Regarding labour precarity, governments should develop mechanisms to facilitate the creation of local ownerships.

Finally, a labour policy should also be specifically designed to ensure that local staff have promotion opportunities in the companies for which they work. Such a measure would imply that international companies involved in activities related to tourism (e.g., resorts, cruise ships, and airports) should have effective career programmes. In the short to medium term, DMOs should take the steps necessary to ensure that the local staff working for these companies attain better positions and higher salaries.

\section{Conclusions}

Tourism in SIDS is devised as a means to enhance the QoL of the residents. The exceptional natural and cultural resources of these locations turn tourism activity into a strong competitive 
advantage with which to combat some of the vulnerabilities associated with SIDS, even when they are not yet consolidated destinations.

This work is an attempt to model the QoL in a destination according to the effects of tourism growth from a macroeconomic perspective. The originality of the work is that this phenomenon is analyzed in terms of the positive impacts of tourism not only on the economy, but also on education and health. The work also offers DMOs an overview of the real effects of tourism on residents' QoL.

Concerning Hypothesis 1, the research has proved that a more significant degree of tourism development enhances the life conditions of residents in SIDS. Thus, tourism can become a driver of economic development in small economies of this kind.

Hypothesis 2 is also valid, since the findings suggest that allocation of resources to the tourism sector affects QoL positively. However, the positive effects of government expenditures on QoL are four times greater than those of private investment. This implies the need to delve deeper into every particular case so that different factors can be identified to explain why private investment has less repercussion on residents' QoL.

The rejection of Hypothesis 3, meanwhile, implies the need to implement specific labour policies in order to fight precarity and strengthen local entrepreneurship.

These findings serve not only to outline the positive effects of tourism activity on SIDS but also to present the model of development that tourism is generating.

With this information, DMOs can reshape this model before tourism grows any further so that the effects of tourism are not incompatible with residents' expectations. It is also important to use these findings to link tourism to the achievement of global goals (UNWTO, 2015) and the policy agendas of SIDS.

Finally, the tourism-QoL interaction in SIDS has been analyzed from an objective point of view based on macroeconomic data. However, future lines of research should focus on measuring the residents' subjective view of their QoL, based on their perception of issues such as material welfare, happiness, and life satisfaction.

Also, it is evident that tourism has been analyzed as a resilient sector that grows regardless of the macroeconomic situation. However, this conception should not be analyzed further until preliminary studies of SIDS are more numerous.

\section{References}

Alder, J., Stankus, A., DeBey, H., \& Dabbadie, L. (2018). A seminar on aquaculture and blue growth development opportunities in Small Island Developing States. FAO Aquaculture Newsletter, 58, 13-14.

Anand, S., \& Sen, A. (2000). The income component of the human development index. Journal of Human Development, 1(1), 83-106.

Andereck, K. L., \& Nyaupane, G. P. (2011). Exploring the nature of tourism and quality of life perceptions among residents. Journal of Travel Research, 50(3), 248-260. https://doi.org/10.1177/0047287510362918

Andrades, L., \& Dimanche, F. (2017). Destination competitiveness and tourism development in Russia: Issues and challenges. Tourism Management, 62, 360-376. https://doi.org/10.1016/j.tourman.2017.05.008 
Andrews, D. W. (1991). Heteroskedasticity and autocorrelation consistent covariance matrix estimation. Econometrica, 59(3), 817-858. https://doi.org/10.2307/2938229

Banerjee, O., Cicowiez, M., \& Gachot, S. (2015). A quantitative framework for assessing public investment in tourism: An application to Haiti. Tourism Management, 51, 157173. https://doi.org/10.1016/j.tourman.2015.05.015

Banwayo-Skeete, P. F., \& Skeete, R. W. (2015) Can Google data improve the forecasting performance of tourist arrivals? Mixed-data sampling approach. Tourism Management, 46(1), 454-464. https://doi.org/10.1016/j.tourman.2014.07.014

Baum, T. (2012). Human resource management in tourism: a small island perspective. International Journal of Culture, Tourism and Hospitality Research, 6(2), 124-132. https://doi.org/10.1108/17506181211233054

Beck, N., \& Katz, J. N. (1995). What to do (and not to do) with time-series cross-section data. American Political Science Review, 89(3), 634-647. https://doi.org/10.2307/2082979

Briguglio, L. (1995). Small island developing states and their economic vulnerabilities. World Development, 23(9), 1615-1632. https://doi.org/10.1016/0305-750x(95)00065-k

Butler, R. W. (1980). The concept of a tourist area cycle of evolution: Implications for management of resources. Canadian Geographer, 24(1), 5-12. https://doi.org/10.1111/j.1541-0064.1980.tb00970.x

Cannonier, C., \& Burke, M. G. (2018). The economic growth impact of tourism in Small Island Developing States: Evidence from the Caribbean. Tourism Economics, 25(1), 85108. https://doi.org/10.1177/1354816618792792

Cellini, R., \& Cuccia, T. (2015). The economic resilience of tourism industry in Italy: What the 'great recession' data show. Tourism Management Perspectives, 16, 346-356. https://doi.org/10.1016/j.tmp.2015.09.007

Chou, M. C. (2013). Does tourism development promote economic growth in transition countries? A panel data analysis. Economic Modelling, 33, 226-232. https://doi.org/10.1016/j.econmod.2013.04.024

Croes, R. (2013). Tourism specialization and economic output in small islands. Tourism Review, 68(4), 34-48. https://doi.org/10.1108/tr-09-2013-0050

Croes, R., \& Rivera, M. (2010). Testing the impact of tourism on competitiveness: The case of Puerto Rico. Tourism Economics, 16(1), 217-234. https://doi.org/10.5367/000000010790872114

Crouch, I. G., \& Ritchie, B. J. R. (2012). Destination competitiveness and its implications for host-community QOL. In M. Uysal, R. Perdue, \& M. J. Sirgy (eds.). Handbook of tourism and quality-of-life research: Enhancing the lives of tourists and residents of host communities (pp. 491-514). Dordrecht: Springer. https://doi.org/10.1007/978-94$\underline{007-2288-0}$

Dalton, H. (1920). The measurement of the inequality of incomes. The Economic Journal, 30(119), 348-361.

Davies, A., \& Quinlivan, G. (2006). A panel data analysis of the impact of trade on human development. Journal of Socio-Economics, 35(5), 868-876. https://doi.org/10.1016/j.socec.2005.11.048 
Dritsakis, N. (2012). Tourism development and economic growth in seven Mediterranean countries: A panel data approach. Tourism Economics, 18(4), 801-816. https://doi.org/10.5367/te.2012.0140

Duffy, L. N., Stone, G., Charles Chancellor, H., \& Kline, C. S. (2016). Tourism development in the Dominican Republic: An examination of the economic impact to coastal households. Tourism and Hospitality Research, 16(1), 35-49. https://doi.org/10.1177/1467358415613118

Dufour, J. M., \& Khalaf, L. (2002). Exact tests for contemporaneous correlation of disturbances in seemingly unrelated regressions. Journal of Econometrics, 106(1), 143170. https://doi.org/10.1016/s0304-4076(01)00093-8

Fahimi, A., Saint Akadiri, S., Seraj, M., \& Akadiri, A. C. (2018). Testing the role of tourism and human capital development in economic growth: A panel causality study of micro-states. Tourism Management Perspectives, 28, 62-70. https://doi.org/10.1016/j.tmp.2018.08.004

Fauzel, S., Seetanah, B., \& Sannassee, R. V. (2017). Analyzing the impact of tourism foreign direct investment on economic growth: Evidence from a small island developing state. Tourism Economics,23(5), 1042-1055. https://doi.org/10.1177/1354816616664249

Gascón, J. (2015). Pro-poor tourism as a strategy to fight rural poverty: A critique. Journal of Agrarian Change, 15(4), 499-518. https://doi.org/10.1111/joac.12087

Genc, R. (2012). Subjective aspects of tourists' quality-of-life (QOL). In M. Uysal, R. Perdue, \& M. Sirgy (eds.). Handbook of tourism and quality-of-life research (pp. 149-167). New York: Springer. https://doi.org/10.1007/978-94-007-2288-0 9

Grampella, M., Martini, G., Scotti, D., \& Zambon, G. (2016). The factors affecting pollution and noise environmental costs of the current aircraft fleet: An econometric analysis. Transportation Research Part A: Policy and Practice, 92, 310-325. https://doi.org/10.1016/j.tra.2016.06.013

Hafiz, M., Hemdi, M. A., \& Ahmad, I. (2016). Does tourism destination competitiveness lead to performance? A case of ASEAN region. Turizam, 64(3), 251-260.

Hampton, M. P., Jeyacheya, J., \& Long, P. H. (2018). Can tourism promote inclusive growth? Supply chains, ownership and employment in Ha Long Bay, Vietnam. Journal of Development Studies, $\quad$ 54(2), 359-376. https://doi.org/10.1080/00220388.2017.1296572

Haq, R., \& Zia, U. (2013). Multidimensional wellbeing: An index of quality of life in a developing economy. Social Indicators Research, 114(3), 997-1012. https://doi.org/10.1007/s11205-012-0186-6

Hair, J. F., Anderson, R. E., Tatham, R. L., \& Black, W. C. (1995). Multivariate data analysis. New York: Macmillan.

Heritage Foundation (2018). Index of economic freedom. https://www.heritage.org/index/ranking

Hess, J., \& Kelman, I. (2017). Tourism industry financing of climate change adaptation: exploring the potential in small island developing states. Climate, Disaster and Development Journal, 2(2), 33-45. https://doi.org/10.18783/cddj.v002.i02.a04

Işik, C. (2015). Foreign direct investment in tourism: panel data analysis of D7 countries. Athens Journal of Tourism, 2(2), 93-103. https://doi.org/10.30958/ajt.2-2-2 
Jackman, M. (2014). Output volatility and tourism specialization in Small Island Developing States. Tourism Economics, 20(3), 527-544. https://doi.org/10.5367/te.2013.0289

Jiang, M., DeLacy, T., Mkiramweni, N. P., \& Harrison, D. (2011). Some evidence for tourism alleviating poverty. Annals of Tourism Research, 38(3), 1181-1184. https://doi.org/10.1016/j.annals.2011.03.008

Kapmeier, F., \& Gonçalves, P. (2018). Wasted paradise? Policies for Small Island States to manage tourism-driven growth while controlling waste generation: the case of the Maldives. System Dynamics Review, 34(1-2), 172-221. https://doi.org/10.1002/sdr.1607

Karimi, M., \& Brazier, J. (2016). Health, health-related quality of life, and quality of life: What is the difference? Pharmacoeconomics, 34(7), 645-649. https://doi.org/10.1007/s40273-016-0389-9

Khan, S. A. R., Qianli, D., SongBo, W., Zaman, K., \& Zhang, Y. (2017). Travel and tourism competitiveness index: The impact of air transportation, railways transportation, travel and transport services on international inbound and outbound tourism. Journal of Air Transport Management, 58 125-134. https://doi.org/10.1016/j.jairtraman.2016.10.006

Kim, K., Uysal, M., \& Sirgy, M. J. (2013). How does tourism in a community impact the quality of life of community residents? Tourism Management, 36, 527-540. https://doi.org/10.1016/j.tourman.2012.09.005

Kubickova, M., Croes, R., \& Rivera, M. (2017). Human agency shaping tourism competitiveness and quality of life in developing economies. Tourism Management Perspectives, 22, 120-131. https://doi.org/10.1016/j.tmp.2017.03.002

Lee, D., Hampton, M., \& Jeyacheya, J. (2014). The political economy of precarious work in the tourism industry in Small Island Developing States. Review of International Political Economy, 22(1), 194-223. https://doi.org/10.1080/09692290.2014.887590

Liburd, J., Benckendorff, P., \& Carlsen, J. (2012). Tourism and quality of life: How does tourism measure up? In R. P. M. Uysal (ed.). Handbook on tourism and QoL Research (pp. 105-132). Dordrecht: Springer. https://doi.org/10.1007/978-94-007-2288-0 7

Lotfi, S., \& Koohsari, M. J. (2009). Analyzing accessibility dimension of urban quality of life: Where urban designers face duality between subjective and objective reading of place. Social Indicators Research, 94(3), 417-435. https://doi.org/10.1007/s11205-009-9438-5

McAlber, M., Shareef, R., \& Hoti, S. (2005). Modeling country risk and uncertainty in small island tourism economics. Tourism Economics, 11(2), 159-183. https://doi.org/10.5367/0000000054183504

McElroy, J. L. (2006). Small island tourist economies across the life cycle. Asia Pacific Viewpoint, 47(1), 61-77. https://doi.org/10.1111/j.1467-8373.2006.00303.x

McGillivray, M., Naudé, W., \& Santos-Paulino, A. U. (2010). Vulnerability, trade, financial flows and state failure in small island developing states. Journal of Development Studies, 46(5), 815-827. https://doi.org/10.1080/00220381003623822

Moghal, Z., \& O'Connell, E. (2018). Multiple stressors impacting a small island tourism destination-community: A nested vulnerability assessment of Oistins, Barbados. Tourism Management Perspectives, 26, 78-88. https://doi.org/10.1016/j.tmp.2018.03.004 
Naudé, W., Santos-Paulino, A. U., \& McGillivray, M. (2009). Vulnerability in developing countries. Tokyo \& New York: UNU Press.

Pentelow, L., \& Scott, D. J. (2011). Aviation's inclusion in international climate policy regimes: Implications for the Caribbean tourism industry. Journal of Air Transport Management, 17(3), 199-205. https://doi.org/10.1016/j.jairtraman.2010.12.010

Pesaran, M. H. (2004). General diagnostic tests for cross section dependence in panels. CESifo Working Paper Series $N^{\circ} 1229$. IZA Discussion Paper $N^{\circ} 1240$.

Pesaran, M. H. (2007). A simple panel unit root test in the presence of cross section dependence. Journal of Applied Econometrics, 22(2), 265-312. https://doi.org/10.1002/jae.951

Pigou, A. (1912). Wealth and welfare. New York: Macmillan.

Pilkington, M., Crudu, R., \& Grant, L. G. (2017). Blockchain and bitcoin as a way to lift a country out of poverty-tourism 2.0 and e-governance in the Republic of Moldova. International Journal of Internet Technology and Secured Transactions, 7(2), 115-143. https://doi.org/10.1504/ijitst.2017.10008012

Podhorodecka, K. (2018). Tourism economies and islands' resilience to the global financial crisis. Island Studies Journal, 13(2), 163-184. https://doi.org/10.24043/isj.43

Praene, J. P., Payet, M., \& Bénard-Sora, F. (2018). Sustainable transition in small island developing states: Assessing the current situation. Utilities Policy, 54, 86-91. https://doi.org/10.1016/j.jup.2018.08.006

Pratt, S. (2015). The economic impact of tourism in SIDS. Annals of Tourism Research, 52, 148-160. https://doi.org/10.1016/j.annals.2015.03.005

Prayag, G., Dookhony-Ramphul, K., \& Maryeven, M. (2010). Hotel development and tourism impacts in Mauritius: Hoteliers' perspectives on sustainable tourism. $\begin{array}{llll}\text { Development Southern } & \text { 6frica, 27(5), }\end{array}$ https://doi.org/10.1080/0376835x.2010.522832

Puig-Cabrera, M., \& Foronda-Robles, C. (2018). El turismo y el alivio de la pobreza: un enfoque desde el prisma de los destinos emergentes en el marco de la Agenda 2030. Investigaciones Turísticas, 16, 1-22. https://doi.org/10.14198/inturi2018.16.01

Pulido-Fernández, J. I., Andrades-Caldito, L., \& Sánchez-Rivero, M. (2015). Is sustainable tourism an obstacle to the economic performance of the tourism industry? Evidence from an international empirical study. Journal of Sustainable Tourism, 23(1), 47-64. https://doi.org/10.1080/09669582.2014.909447

Rahman, T., Mittelhammer, R. C., \& Wandscheider, P. (2005). Measuring the quality of life across countries: A sensitivity analysis of well-being indices (No. 2005/06). Research Paper, UNU-WIDER, United Nations University (UNU).

Read, R. (2018). The determinants and growth effects of foreign direct investment in small economies. In L. Briguglio (ed.). Handbook of small states: Economic, social and environmental issues. https://doi.org/10.4324/9781351181846-15

Ridderstaat, J., Croes, R., \& Nijkamp, P. (2016). The tourism development-quality of life nexus in a small island destination. Journal of Travel Research, 55(1), 79-94. https://doi.org/10.1177/0047287514532372 
Robinson, S. A. (2017). Climate change adaptation trends in small island developing states. Mitigation and Adaptation Strategies for Global Change, 22(4), 669-691. https://doi.org/10.1007/s11027-015-9693-5

Sari, A. (2017). E-government attempts in Small Island Developing States: The rate of corruption with virtualization. Science and Engineering Ethics, 23(6), 1673-1688. https://doi.org/10.1007/s11948-016-9848-0

Scheyvens, R., \& Momsen, J. (2008). Tourism and poverty reduction: Issues for small island states. Tourism Geographies, $\quad 10(1), \quad 22-41$. https://doi.org/10.1080/14616680701825115

Scheyvens, R., \& Russell, M. (2012). Tourism and poverty alleviation in Fiji: Comparing the impacts of small-and large-scale tourism enterprises. Journal of Sustainable Tourism, 20(3), 417-436. https://doi.org/10.1080/09669582.2011.629049

Schubert, S. F., Brida, J. G., \& Risso, W. A. (2011). The impacts of international tourism demand on economic growth of small economies dependent on tourism. Tourism Management, 32(2), 377-385. https://doi.org/10.1016/j.tourman.2010.03.007

Seetanah, B. (2011). Assessing the dynamic economic impact of tourism for island economies. Annals of Tourism Research, 38(1), 291-308. https://doi.org/10.1016/j.annals.2010.08.009

Shakeela, A., Ruhanen, L., \& Breakey, N. (2011). The role of employment in the sustainable development paradigm: The local tourism labor market in small island developing states. Journal of Human Resources in Hospitality \& Tourism, 10(4), 331-353. https://doi.org/10.1080/15332845.2011.588493

Shareef, R., \& McAleer, M. (2005). Modeling international tourism demand and volatility in small island tourism economies. International Journal of Tourism Research, 7(6), 313-333. https://doi.org/10.1002/jtr.538

Sharpley, R. (2009). Tourism development and the environment: Beyond sustainability? Abingdon: Routledge.

Sharpley, R., \& Ussi, M. (2014). Tourism and governance in Small Island Developing States (SIDS): The case of Zanzibar. International Journal of Tourism Research, 16(1), 87-96. https://doi.org/10.1002/jtr.1904

Singh, D. R. (2008). Small Island Developing States (SIDS): Tourism and economic development. Tourism Analysis, 13(5-6), 629-636. https://doi.org/10.3727/108354208788160432

Suntikul, W., Pratt, S., I Kuan, W., Wong, C. I., Chan, C. C., Choi, W. L., \& Chong, O. F. (2016). Impacts of tourism on the quality of life of local residents in Hue, Vietnam. Anatolia, 27(4), 405-420. https://doi.org/10.1080/13032917.2016.1138234

Surroop, D., Raghoo, P., \& Bundhoo, Z. M. (2018). Comparison of energy systems in Small Island Developing States. Utilities Policy, 54, 46-54. https://doi.org/10.1016/j.jup.2018.07.006

Suryawardani, I. G. O., Bendesa, I. K. G., Antara, M., \& Wiranatha, A. S. (2014). Tourism leakage of the accommodation sector in Bali. ASEAN Journal on Hospitality and Tourism, 13(1), 3-18.

Tang, C. F., \& Abosedra, S. (2016). Does tourism expansion effectively spur economic growth in Morocco and Tunisia? Evidence from time series and panel data. Journal of 
Policy Research in Tourism, Leisure and Events, 8(2), 127-145. https://doi.org/10.1080/19407963.2015.1113980

Telfer, D.J., \& Sharpley, R. (2016). Tourism and development in the developing world. Abingdon: Routledge.

UN (2014). SIDS Accelerated Modalities of Action (SAMOA) Pathway. United Nations.

UN (2018). Small Island Developing States. United Nations. http://sustainabledevelopment.un.org/topics/sids/list

UNCTAD (2007). FDI in tourism: The development dimension. United Nations Conference on Trade and Development, Ginebra, Sweden.

UNCTAD (2018). World investment report. United Nations Conference on Trade and Development, Ginebra, Sweden.

UNDP (1990). Human development report. United Nations Development Programme: New York, USA.

UNDP (2018). Human development data. United Nations Development Programme: New York, USA. http://hdr.undp.org/en/data

UNWTO (2015). Tourism in Small Island Developing States (SIDS): Building a more sustainable future for the people of islands. Madrid: World Tourism Organisation. https://doi.org/10.18111/9789284416257

UNWTO (2016). First World Conference on Tourism for Development. http://media.UNWTO.org/es/press-release/2016-05-27/primera-conferenciamundial-sobre-turismo-para-el-desarrollo-el-primer-mini. Madrid: Organización Mundial del Turismo.

UNWTO (2018a). Yearbook of tourism statistics, compendium of tourism statistics and data files. Madrid: World Tourism Organisation. https://doi.org/10.18111/9789284415939

UNWTO (2018b). Tourism for development report: Vol. I. Madrid: World Tourism Organisation.

Uysal, M., Sirgy, M. J., Woo, E., \& Kim, H. L. (2016). Quality of life (QOL) and well-being research in tourism. Tourism Management, 53, 244-261. https://doi.org/10.1016/j.tourman.2015.07.013

Westerlund, J. (2008). Panel cointegration tests of the Fisher effect. Journal of Applied Econometrics, 23(2), 193-233. https://doi.org/10.1002/jae.967

White, H. (1980). A heteroskedasticity-consistent covariance matrix estimator and a direct test for heteroskedasticity. Econometrica, 48(4), 817-838. https://doi.org/10.2307/1912934

Woo, E., Kim, H., \& Uysal, M. (2015). Life satisfaction and support for tourism development. Annals of Tourism Research, 50, 84-97. https://doi.org/10.1016/j.annals.2014.11.001

WTTC (2016). Economic impact reports 2016. London: World Travel \& Tourism Council.

WTTC (2018). Data gateway. https://tool.wttc.org/. London: World Travel \& Tourism Council.

Yu, C. P., Cole, S. T., \& Chancellor, C. (2016). Assessing community quality of life in the context of tourism development. Applied Research in Quality of Life, 11(1), 147-162. https://doi.org/10.1007/s11482-014-9359-6 
Miguel Puig-Cabrera \& Concepción Foronda-Robles 